\title{
The Influence of Goal Orientation and Self-Regulation Tactics on Sales Performance: A Longitudinal Field Test
}

Don VandeWalle

Southern Methodist University

Steven P. Brown

William L. Cron

Southern Methodist University

John W. Slocum, Jr.

Southern Methodist University

Follow this and additional works at: https://scholar.smu.edu/business_workingpapers

Part of the Business Commons

This document is brought to you for free and open access by the Cox School of Business at SMU Scholar. It has been accepted for inclusion in Historical Working Papers by an authorized administrator of SMU Scholar. For more information, please visit http://digitalrepository.smu.edu. 
The Influence of Goal Orientation and Self-regulation Tactics on Sales

Performance: A Longitudinal Field Test

Working Paper 98-0401

by

Don VandeWalle

Steven P. Brown

William L. Cron

John W. Slocum, Jr.

Don VandeWalle

Edwin L. Cox School of Business

Southern Methodist University

Dallas, Texas 75275

* This paper represents a draft of work in progress by the authors and is being sent to you for information and review. Responsibility for the contents rests solely with the authors, and such contents may not be reproduced or distributed without written consent by the authors. Please address all correspondence to Don VandeWalle. 
The Influence of Goal Orientation and Self-regulation Tactics on Sales Performance:

\title{
A Longitudinal Field Test
}

\author{
Running Head: Sales \\ Don VandeWalle \\ Steven P. Brown \\ William L. Cron \\ John W. Slocum, Jr. \\ Organizational Behavior and Business Policy Department \\ Cox School of Business \\ Southern Methodist University \\ PO Box 750333 \\ Dallas, Texas 75275-0333 \\ E-mail: dvande@mail.cox.smu.edu \\ Phone: $214-768-1239$ \\ Fax: 214-768-4099
}

Author Note: A preliminary version of this article was presented at the annual meeting of the Society for Industrial and Organizational Psychology, Dallas, Texas, April, 1998. We thank Ellen Jackofsky and Ed Locke for their comments on an earlier version of this article.

File: GOSALES3.DOC

Date: $04 / 6 / 98$ 


\title{
The Influence of Goal Orientation and Self-regulation Tactics on Sales Performance: A Longitudinal Field Test
}

\author{
Abstract \\ In a longitudinal field study with salespeople, we investigated the influence of goal \\ orientation on sales performance. As hypothesized, a learning goal orientation had a positive \\ relationship with sales performance. This relationship was fully mediated by three self- \\ regulation tactics -- goal setting, effort and planning. In contrast, a performance goal orientation \\ was unrelated to sales performance. These results suggest that a focus on skill development, \\ even for a veteran work force, is likely to be associated with high performance. Management \\ should seek evidence of a learning goal orientation when selecting new employees, while \\ avoiding an excessive focus on performance goal orientation without a comparable skill- \\ development focus.
}


In recent years, there has been a strong, renewed interest in research on the individual difference determinants of work behavior and performance (Kanfer, 1990a, 1990b; Kanfer 1992). An individual difference that has been the subject of this renewed interest is goal orientation (see Button, Mathieu, and Zajac, 1996; and Farr, Hoffman, and Ringenbach, 1993 for extensive discussions of the implications of goal orientation for $\mathrm{I} / \mathrm{O}$ psychology research).

Our understanding of goal orientation has emerged from the work of Carol Dweck and her colleagues (Dweck, 1986; Dweck \& Leggett, 1988; Elliott \& Dweck, 1988). They conceptualized the broader goals pursued by individuals as a personality dimension and proposed that individuals have goal orientations -- individual differences for goal preferences in achievement settings. She identified two major classes of goal orientations: (a) learning goal orientation to develop competence by acquiring new skills and mastering new situations, and (b) performance goal orientation to demonstrate and validate one's competence by seeking favorable judgments and avoiding negative judgments (see also Nicholls, 1984, for a similar conceptualization of goal orientation).

Goal orientation creates the mental frameworks that individuals use to interpret and respond to achievement situations (Dweck \& Leggett, 1988; Elliott \& Dweck, 1988). These interpretation and response patterns are especially prominent when individuals are confronted with a challenging task. Individuals with performance goal orientations view a challenging task as a threat because there is the risk of failure, that would demonstrate their inadequate ability. In challenging situations, these individuals pursue a maladaptive response pattern in that they withdraw from the task, make negative ability attributions, and report decreased interest in the task. Individuals with learning goal orientations on the other hand, view a challenging task as an opportunity for growth and development. In such situations, these individuals pursue an adaptive 
response pattern in that they persist, escalate effort, engage in solution-oriented self instruction, and report enjoying the challenge.

Previous research has examined the relationship of goal orientation with various performance outcomes. In a longitudinal field study with undergraduate students, Phillips and Gully (1997) found a positive relationship between a learning goal orientation and exam score and an insignificant relationship between a performance goal orientation and exam score. In three studies with large samples of undergraduate psychology students, Button et al. (1996) found a positive relationship between a learning goal orientation and grade point average and an insignificant relationship between a performance goal orientation and grade point average.

There is also evidence that goal orientation, when induced as a state, influences performance outcomes. ${ }^{1}$ In a laboratory experiment with undergraduate students, Butler (1993) used instructions to create the equivalent of learning and performance goal orientations. While working on a series of problem solving tasks, participants in the learning condition improved their task performance over the series, but those in the performance condition did not. In another laboratory experiment with students, Block, Roney, Geetter, Lopez, and Yang (1995) manipulated goal orientation and had the participants complete a decision-making exercise. As hypothesized, the exercise solutions of the individuals in the learning condition were of much higher quality and quantity than were the solutions of the individuals in the performance condition.

${ }^{1}$ There is considerable evidence of goal orientation existing as a stable individual difference (e.g., Button et al., 1996; VandeWalle, 1997), but goal orientation can also be influenced by situational cues about effort, competition, evaluation standards and rewards (Ames, 1992; Nicholls, 1984). When the situation offers no cues as to what goals are favored, the individual difference goal preferences should dominate. If, however, the situation offers strong cues, goal preferences can be overridden by the situational cues. This research focuses on the individual difference aspect of goal orientation. 
These studies provide initial evidence that a learning goal orientation is more likely than a performance goal orientation to lead to positive performance outcomes. There are several reasons for concern, however, about the extension of these findings to workplace settings. First, much of the goal orientation research has been conducted with young children (i.e., Elliott and Dweck, 1988), or with college students (i.e., Button et al., 1996), and often in laboratory settings (i.e., Block et al., 1995). Further, many of these studies have looked at the influence of state rather trait goal orientation on performance (e.g., Butler, 1993; Stevens \& Gist, 1997). Second, the published research conducted in a field setting with employees (Sujan, Weitz, \& Kumar, 1994) used a cross-sectional research design and collected performance data with self-report measures. Third, scholars (e.g., Kanfer, 1990b) have discussed the importance of explicating the intermediate motivational mechanisms that mediate the relationship of an individual difference with job performance. At this point, however, we still have a very limited understanding of the mechanisms that mediate the relationship of goal orientation and job performance.

The purpose of this research was to study the influence of goal orientation on employee performance. To address the above three concerns, we conducted our research in a field setting with the employees of a medical supplies distributor. A longitudinal research design was used and actual performance was assessed with sales data from company records. In addition, we collected data on the self-regulation tactics that were hypothesized to mediate the relationship of goal orientation and performance. In the subsequent sections, we develop the theoretical model, starting with the proposed relationship of goal orientation with three self-regulation tactics. 


\section{Goal Orientation and Self-regulation Tactics}

Why do individuals with a learning goal orientation appear to have a performance advantage? Researchers in educational psychology (e.g., Ames \& Archer, 1988; Miller, Behrens, Greene, \& Newman, 1993) have suggested that a learning goal orientation predisposes individuals to employ self-regulation strategies in pursuit of their mastery focus. Consistent with Kanfer (1990b), we define self-regulation as the cognitive process that determines the transformation of motivational force into behavior and performance. Individuals with performance goal orientations are less concerned with mastery, and should thus be less predisposed to use self-regulation strategies than individuals with a learning goal orientation. Kanfer (1990a, 1990b, 1992) made a similar argument in the I/O psychology literature and suggested that goal orientation affected job performance through its influence on self-regulation activities. Based on the personal characteristics associated with learning and performance goal orientations, we propose that individuals with a learning goal orientation, compared to those with a performance goal orientation, will engage in greater usage of three self-regulation tactics -- goal setting, effort and planning. In developing our hypotheses, the two self-regulation tactics of effort and planning are framed from the perspective of conscious intentions. This approach is based on the theory that individuals plan what they are going to do and act according to their plans (Gollwitzer, 1996; Ryan, 1970). We thus use the terms intended effort and intended planning.

Goal Setting

Individuals with high learning and performance goal orientations should differ in their level of self-set goal because of how each party frames a challenging goal. Individuals with a 
learning goal orientation are primarily concerned with developing their skills and ability. Given this focus, a difficult goal should be of interest because it provides a challenging opportunity that can lead to personal growth. In contrast, individuals with a performance goal orientation are concerned with obtaining positive evaluations about their ability. Given this focus, a difficult goal should be of lower interest because it provides a greater potential for failure. As goal difficulty increases, the probability of obtaining a positive evaluation via goal attainment decreases.

There are no published reports of a direct test of the influence of goal orientation on selfset goal levels. Several survey studies, however, have found that a learning goal orientation has positive relationships with a preference for challenging tasks (Ames \& Archer, 1988; Archer, 1994), the use of goal setting procedures (Miller et al., 1993) and optimism (VandeWalle, 1996). In contrast, a performance goal orientation had insignificant or negative relationships with these three constructs. We speculate that individuals who prefer challenging tasks, use goal setting procedures, and are optimistic (i.e., those with a learning goal orientation) should also be more willing to set difficult goals. We thus hypothesize:

Hypothesis 1: Learning goal orientation will be positively related to, and performance goal orientation will be unrelated to, the level of self-set goal.

Intended Effort

Goal orientation influences how individuals view effort expenditures (Ames, 1992). Individuals with a learning goal orientation believe that effort leads to success. Effort is viewed as a means for activating current ability for task achievement and as a means for developing the ability needed for future task mastery. Individuals with a performance goal orientation, however, perceive ability as a fixed attribute. Therefore, they are unlikely to view effort as a means for 
developing the ability needed for task mastery. Rather, performance oriented individuals view high effort as an indicator of low ability because they reason that a capable person would not need to try so hard to accomplish a task.

Two additional goal orientation characteristics are also relevant. VandeWalle (1996, 1997) found that a learning goal orientation had a positive relationship with the desire to work hard (Helmreich \& Spence, 1978) and optimism (Scheier \& Carver, 1985). In contrast, a performance goal orientation had negative relationships with each construct. Given that they believe that effort leads to success, enjoy hard work, and are optimistic, individuals with a learning goal orientation should be willing to commit to the effort needed to attain high performance.

Finally, we note that Stevens and Gist (1997) found that individuals exposed to a mastery orientation training program (compared to those exposed to a performance orientation training program) indicated that they planned to use more effort for an upcoming negotiation exercise. Based on the above evidence, we thus hypothesize:

Hypothesis 2: Learning goal orientation will be positively related to, and performance goal orientation will be unrelated to, the level of intended effort.

\section{Intended Planning}

In complex task situations, performance outcomes often require individuals to develop a plan to achieve a high level outcome. A study by Sujan et al. (1994) provides potential evidence that individuals with a learning goal orientation would be more likely than individuals with a performance goal orientation to commit themselves to developing a plan for performance success. Sujan et al. examined the influence of goal orientation on "working smart" -- a form of 
self-regulation which they defined as behavior directed toward developing and using the knowledge needed to succeed in sales situations. Working smart had a strong, positive relationship with learning goal orientation but had an insignificant relationship with a performance goal orientation. The working smart measure included items that assessed the planning dimension of working smart, but Sujan et al. did not report the specific relationship of the planning dimension with either goal orientation. Thus, this specific relationship remains to be tested.

The results of two additional studies also suggest that individuals with a learning goal orientation are more likely than individuals with a performance goal orientation to engage in planning. For participants working on an experimental task, Button et al. (1996) found a positive relationship between a performance goal orientation and the occurrence of obtrusive (off-task) thoughts, but a learning goal orientation was unrelated to such thoughts. VandeWalle (1996) found a positive relationship between conscientiousness (Costa \& McCrae, 1992) and learning goal orientation. Individuals who are able to stay on task, and are conscientious, should be more predisposed to planning activities.

Hypothesis 3: Learning goal orientation will be positively related to, and performance goal orientation will be unrelated to, the level of intended planning.

\section{Self-regulation Tactics and Performance}

Given that individuals have sufficient ability and knowledge, the three self-regulation tactics in our model should have positive relationships with performance. First, one of the most robust findings in the psychology literature is the positive relationship between goal level and performance (Locke \& Latham, 1990; Pinder, 1998). Second, many motivation theories propose 
a positive relationship between effort and performance (e.g., Porter \& Lawler, 1968), and there is empirical support for this relationship (e.g., Brown \& Leigh, 1996; Brown \& Peterson, 1994). Third, the use of analytical strategies and planning enhances performance (Smith, Locke, \& Barry, 1990; Wood \& Bandura, 1989). In sum, we hypothesize:

Hypothesis 4: The level of goal setting, intended effort and intended planning will be positively related to performance.

\section{Mediation of Learning Goal Orientation and Performance}

Finally, we state explicitly what is implicit in the combination of our prior hypotheses -the three self-regulation tactics mediate the relationship of learning goal orientation and performance. We expect that this relationship will be fully mediated. That is, the relationship between learning goal orientation and performance will not be significant when the effects of the mediators are controlled statistically.

Our mediated model is consistent with the theorizing of several scholars. Lee, Locke, and Latham (1989) proposed that self-set goals mediate the relationship of personality and performance. Our model is also consistent with Kanfer's (1992) heuristic framework of motivational theories and constructs. She proposed that "distal" constructs, such as personality, do not directly affect behavior. Rather, distal constructs influence more "proximal" constructs, such as goals and intentions, and these proximal constructs more strongly influence behavior. More recently, Kanfer, Ackerman and Heggestad (1996) discussed the possibility of an individual difference basis for the self-regulation skills that individuals bring to a situation. They further suggested that these self-regulation differences might predict performance. In summary, 
there is a solid body of theory that supports our proposal of a mediated model. We thus hypothesize:

Hypothesis 5: The level of goal-setting, intended effort and intended planning will mediate the relationship between learning goal orientation and performance.

In sum, the purpose of this study was to examine the relationship of goal orientation and performance. We proposed that a learning goal orientation would have positive relationships with the levels of goal setting, of intended effort, and of intended planning. The use of these tactics would lead to higher performance. In contrast, we expected that a performance goal orientation would be unrelated to performance.

\section{Method}

\section{$\underline{\text { Overview }}$}

We tested the hypotheses with data collected in conjunction with a quarterly product promotion implemented by a medical supplies distributor. This setting was considered to be more appropriate than a longer period of time, annual sales for instance, because the performance results are more tractable and less likely to be influenced by environmental factors outside of the sales force's control. At the start of the product promotion, the distributor's salespeople completed a questionnaire that included measures of learning and performance goal orientations and the self-regulation tactics to be used during the promotion. Data on actual sales were collected at the conclusion of the product promotion.

\section{Sample}

The participants in the study were the salespeople of a medical supplies distributor located in the southwest. The salespeople represented over 2000 lines of medical supplies and 
equipment and had cumulative annual sales of over $\$ 140$ million. The salespeople were assigned geographic territories and had an established list of customers within their territory. The salespeople were paid on commission on gross margin, and the average annual commission income was $\$ 43,000$ per salesperson.

The participants were predominantly men $(84.3 \%)$, and $74 \%$ were college graduates. The mean age was 38.63 years $(\underline{\mathrm{SD}}=9.15)$, and the average organizational tenure was 10.35 years $(\underline{\mathrm{SD}}=8.37)$.

\section{Design and Procedure}

The study was conducted with reference to a specific product promotion offered by the focal organization in conjunction with a supplier. The promoted product was a piece of medical equipment with an average unit price of approximately $\$ 5,400$. Salespeople received a $\$ 300$ bonus for each unit of the promoted product they sold. This type of promotion is commonly implemented by the distributor to give salespeople an incentive to devote exceptional selling effort to a limited number of products while still performing the other selling and customer service activities for which they are responsible. This promotion had the characteristics of a "challenging task" in that salespeople had to deviate from their normal customer calling patterns to be highly successful in the promotion.

Consistent with the distributor's standard practices, the product promotion was introduced at the company's quarterly sales meeting. During the meeting, the salespeople completed a questionnaire that included measures of goal orientation and self-regulation tactics (goals, effort and planning). Management encouraged salespeople to set goals for this promotion but did not assign a specific goal. The promotion lasted for three months. At the end of the promotion, we obtained from company records the actual unit sales of each salesperson. 
Of the 167 salespeople, 158 provided complete data on the quarterly sales meeting questionnaire, and we obtained matching sales data on 153 salespeople, representing a $91.6 \%$ yield rate.

Measures

The descriptive statistics, reliability estimates and intercorrelations of the measures in this study are presented in Table 1.

Goal Orientation. The two goal orientation dimensions were measured using 11 items from a scale that was previously developed and validated by Sujan et al. (1994) and Ames and Archer (1988). Learning goal orientation was measured with six items that asked the salespeople the extent to which they valued development of their sales skills. A sample item read, "Learning how to be a better salesperson is of fundamental importance to me." Performance goal orientation was measured with five items that asked the salespeople the extent to which they valued others knowing about their sales accomplishments. A sample item read, "I very much want my co-workers to consider me to be good at selling." The items used a 7-point response format ranging from 1 (strongly disagree) to 7 (strongly agree). Exploratory factor analysis (principal components with oblique rotation) of the data for the 11 items produced two factors, which corresponded to the learning and performance goal orientations. The two factors accounted for $52 \%$ of the variance. The items and factor analysis results are reported in Appendix A.

Goal Level. One item asked the salespeople to state the number of units (the promoted piece of medical equipment) that they intended to sell. The salespeople were capable of and comfortable with setting personal goals for this promotion, because this piece of equipment was promoted annually. 
Intended Effort. Intended effort was measured by three items that asked the salespeople to rate how much time, work intensity, and overall effort they intended to put into the product compared to other salespeople. The items used a five-point response scale that ranged from 1 (much less than average) to 5 (much more than average).

Intended Planning. We assessed two types of planning activities that could be used as strategies during the product promotion. Five items asked the salespeople about how much planning they intended to do for their sales territory. A sample item read, "Each week I will make a plan for what I need to accomplish regarding this promotion." Three items asked the salespeople about how much planning they intended to do for their current accounts. A sample item read, "I will target particular accounts for this promotion." The items used a 5-point response format ranging from 1 (strongly agree) to 5 (strongly disagree). The responses were reverse coded to $5=\underline{\text { strongly agree }}$ so that the response format matched the order of the other variables. Exploratory factor analysis (principal components with oblique rotation) of the study data for the eight items produced two factors, which corresponded to general territory and account-specific planning. The two factors accounted for $61 \%$ of the variance.

The items and validation evidence for the intended effort and intended planning measures are reported in Brown, Cron, and Slocum (1997).

Sales. Sales was measured as the actual number of units sold during the promotion and was obtained from company records at the end of the product promotion. Sales volume is a commonly used measure of performance quantity in sales force research (Churchill, Ford, \& Walker, 1983) and practice (Jackson, Schlacter, \& Wolfe, 1995). Sales volume is an especially appropriate measure of performance in this setting since the primary focus of the sales promotion was to sell products and the goal level was stated in the number of units to be sold. 


\section{Results}

Hypotheses 1-3 predicted that learning goal orientation would be positively related to the self-regulation tactics and that performance goal orientation would be unrelated to the selfregulation tactics. We tested these hypotheses with a multivariate regression procedure. As discussed by Stevens (1996), this procedure provides an omnibus multivariate test (Rao's F approximation) that determines whether there is a significant relationship between two sets of variables (i.e., the independent and dependent variables) and takes into account the correlations among the dependent variables. The procedure also provides the regression equations and univariate Fs that are based on each dependent variable being regressed separately on the predictor(s). The univariate analysis does not take into account the correlations among the dependent variables, so for our analysis, the bivariate regression beta coefficients are equivalent to correlation coefficients. As shown in Table $2 a$ and $2 b$, the omnibus test was statistically significant for learning goal orientation $(\underline{F}=11.60, \underline{p}<.001)$, but was not significant for performance goal orientation $(\underline{F}=2.31, \underline{p}=.06)$. The results suggest that learning goal orientation predicted a significant amount of variance in the set of self-regulation tactics, but a performance goal orientation did not.

For the univariate effects for Hypotheses 1 through 3, we present the regression beta coefficients and compare the strength of the relationships of the learning and performance goal orientations with each mediator. Because a statistical test is not available to directly compare the beta coefficients, we instead compared the equivalent correlation coefficients from Table 1.

Because the two correlations for each hypotheses are computed from the same sample and are 
computed using a common variable (the focal mediator), we used the Hotelling-Williams test (Williams, 1959a, 1959b) which accounts for these dependencies.

Hypothesis 1 was supported. Learning goal orientation was positively related to the level of goal setting $(\underline{\beta}=.30, \underline{p}<.001)$ but performance goal orientation was not $(\underline{\beta}=.11, \underline{p}=.16)$. Based on the Hotelling-Williams test, the coefficients were significantly different, $\underline{t}(150)=2.21$, $\mathrm{p}<.05$. Hypothesis 2 was also supported. Learning goal orientation was positively related to intended effort $(\underline{\beta}=.33, \mathrm{p}<.001)$ but performance goal orientation was not $(\underline{\beta}=.07, \underline{p}=.41)$. The coefficients were significantly different, $\mathrm{t}(150)=3.06, \mathrm{p}<.01$. Hypothesis 3 was partially supported. Learning goal orientation was positively related to both intended territory planning ( $\underline{\beta}$ $=.44, \underline{\mathrm{p}}<.001)$ and account planning $(\underline{\beta}=.37, \underline{\mathrm{p}}<.001)$. Contrary to expectations, performance goal orientation had positive, although much weaker relationships, with both intended territory planning ( $\underline{\beta}=.17, \underline{p}=.03)$ and account planning $(\underline{\beta}=.20, \underline{p}=.01)$. However, the learning goal orientation coefficients were significantly stronger than the performance goal orientation coefficients for territory planning, $\mathrm{t}(150)=3.30, \underline{\mathrm{p}}<.01$, and for account planning, $\mathrm{t}(150)=2.02$, $\underline{p}<.05$.

Next, we tested the influence of the self-regulation tactics on sales performance. The results of a multiple regression analysis are presented in Table 3 and indicate strong support for hypothesis 4 . Goal level $(\underline{\beta}=.38, \underline{\mathrm{p}}<.001)$, intended effort $(\underline{\beta}=.21, \underline{\mathrm{p}}<.01)$, intended territory planning $(\underline{\beta}=.22, \underline{\mathrm{p}}<.01)$, and intended account planning $(\underline{\beta}=.15, \underline{\mathrm{p}}<.01)$ were all related to sales performance.

Hypothesis 5 proposed that the self-regulation tactics would mediate the relationship between learning goal orientation and performance. We tested the hypothesis with the three-step mediated regression method recommended by Baron and Kenney (1986). With this approach, 
three conditions must be met in order to establish mediation. First, the independent variable (learning goal orientation) must be related to the mediators (self-regulation tactics). As shown in Table 2, this condition was met for all four mediators. Second, the independent variable must be related to the dependent variable. As shown in Table 1, this condition was met by the statistically significant correlation of learning goal orientation and performance. Third, the effect of the independent variable on the dependent variable must be significantly reduced or disappear when jointly considered with the mediator variables. Table 4 shows the results of a multiple regression analysis in which performance was simultaneously regressed on learning goal orientation and the four mediators. The betas for all four mediators remained statistically significant while the beta of learning goal orientation disappeared $(\underline{\beta}=.00, \underline{p}=.94)$. These results suggest that the four self-regulation tactics completely mediate the relationship of learning goal orientation and performance.

As a supplementary analysis for Hypothesis 5, path coefficients for the hypothesized mediated model were estimated using LISREL 8 (Jöreskog \& Sörbom, 1993). The observed indicators for the constructs were combined into single index measures equal to the arithmetic mean of the item scores. The values of the paths from the latent constructs to their observed indicators were fixed to equal the square root of the measure reliability, and the error variances of the indicators were set equal to one minus the measure reliability (Loehlin, 1992). As noted by Hoyle (1995), the growing dissatisfaction with the $\chi^{2}$ goodness-of-fit test has led to development of a number of descriptive fit indexes. Because these fit indexes do not all follow the same logic, Hoyle recommended the use of multiple indexes. We follow Hoyle's recommendation and report five fit indexes. 
The fit of the model to the data produced a $\chi^{2}(7, \underline{N}=153)$ of $11.36(\underline{p}=.12)$, a comparative fit index of .99 , a goodness of fit index of .97 , a normed fit index of .97 , an incremental fit index of .99 , and a root mean square residual of .07 . All of these indexes suggest a good fit of the model to the data. The parameter estimates for the structural model are reported in Figure 1. All of the parameters are in the hypothesized positive direction and are significant at the .01 level.

\section{Discussion}

A central finding of our research is that it takes more than just "wanting to look good," i.e., appearing to others to have high ability, to achieve job performance success. Rather, one needs to have the desire to develop the skills required for success. Our analysis of the data revealed that a learning goal orientation led to higher sales performance and that this relationship was completely mediated by the three self-regulation tactics. The regression analysis for this mediated model explained $60 \%$ of the variance in objectively measured sales performance. In contrast, performance goal orientation was not associated with sales performance.

\section{$\underline{\text { Research Implications }}$}

Scholars have noted a lack of consistent effects for individual difference variables on goal setting (e.g., Dipboye, Smith, \& Howell, 1994). The finding in this study of a strong, positive influence of learning goal orientation on the level of goal setting is thus especially interesting. Our ability to find this effect was probably enhanced by following research design recommendations of Locke and Latham (1990).

First, Locke and Latham (1990) proposed that as individuals gain experience on complex tasks, the effects of personality variables on goal setting should increase as the effect of initial 
ability decreases. With average tenure of 10 years, the salespeople in our study were veterans. Second, individual differences are more likely to influence self-regulation and work performance in work situations where there is free choice about behavior (Weiss \& Adler, 1984). In this research, there was a general understanding by the salespeople that management expected a minimum goal of one unit, but the goal choice was unspecified beyond that minimum. Third, the goals in the study were quite meaningful in that the sales people earned a $\$ 300$ bonus for each unit sold and the performance results were posted publicly. Fourth, the goal was proximal in nature (a 90 day period), and goal attainment was measured with objective data (number of units sold). Finally, the emerging nomological network of goal orientation (e.g. Button et al., 1996; VandeWalle, 1996, 1997) allowed us to develop a strong conceptual foundation for the theoretical model.

Although a strength of this study was the discrete time period of 90 days, it would be interesting to explore the longer-term effect of goal orientation on self regulation tactics and performance. One approach would be to assess the goal orientations of an entry level cohort and then to track during their early career the pattern of their self-regulation tactics and performance. Such research would help inform the use of goal orientation for employee selection and for employee development.

Another strength of this study was that we removed many potential sources of extraneous variance by assessing the performance of individuals in one profession (sales), with a common, objective metric - actual unit sales of the promotional product. This constrained research setting, however, raises the issue of generalizability of the results. For example, the occurrence of the product promotional campaign and the request for individuals to actually record their goals could have triggered the study participants to be more cognizant than normal of the goals they set for 
themselves. We note, however, that the participants were quite experienced with this type of promotional program as it is a standard operating procedure in this sales context. Also, given the prevalence of such promotional programs, an understanding of the influence of goal orientation in this setting is of value. At this time, however, our results are most clearly generalizable to situations where (a) individuals can make conscious choices about the goals they set, (b) there is a clear performance-reward relationship, (c) the metrics used to measure performance are known and quantifiable, (d) and performance feedback is clear and prompt. Thus, there is an excellent opportunity for future research to examine the role of goal orientation when other performance measures in other settings are used, e.g., annual sales, customer feedback, customer retention, and behavioral criteria. Finally, the generalizability of the results will also need to be tested for employees in non-sales professions, in other industries, for less-seasoned employees, etc.

Future research should also consider how the relationship of goal orientation and performance is mediated by other self-regulation tactics. For example, feedback seeking behavior (Ashford \& Cummings, 1983) would seem to be especially beneficial to salespeople as it could help them to develop their sales delivery, communication and customer management competencies. Given that VandeWalle and Cummings (1997) found a positive relationship between a learning goal orientation and feedback seeking, feedback seeking may also mediate the goal orientation-performance relationship. That is, salespeople with a high learning goal orientation might seek feedback from peers, superiors and customers on ways to improve their sales techniques.

Finally, future research should investigate the role that self-efficacy plays in the goal orientation-performance relationship. For example, Stevens and Gist (1997) used a training program to induce learning and performance goal orientations. In a subsequent negotiation 
exercise, they found that among performance-oriented trainees, self-efficacy had a positive relationship with negotiation outcomes, but there was no relationship between self-efficacy and negotiation outcomes for mastery-oriented trainees. Although their research studied state goal orientation, we believe that self-efficacy enhancement could also be useful for individuals with a high trait level of a performance goal orientation. Self-efficacy enhancement might be especially valuable when attempts to raise the level of learning goal orientation are unsuccessful.

\section{$\underline{\text { Managerial Implications }}$}

With regard to employee selection, it would appear to be beneficial to screen applicants on the basis of a learning goal orientation. A learning goal orientation should especially be of value when a sales job is more than simple order generating, and there is a substantial need to develop sales competencies, customer service competencies, and product knowledge to succeed at the job. The longitudinal research that was suggested earlier would further inform the procedures needed to implement this recommendation since the participants in this study were already veteran salespeople.

Our findings also have implications for the management of current employees. First, changing the attributions that individuals make about their ability and performance can enhance a learning goal orientation. Individuals with a learning goal orientation perceive ability as a malleable attribute (Dweck \& Leggett, 1988) and perceive effort as a key cause of their performance success (Duda \& Nicholls, 1992). Task performance may be enhanced for some individuals by training them to understand that many forms of ability can be developed and that effort is an important determinant of performance success. (See Ames, 1992, for additional recommendations on procedures to enhance a learning goal orientation.) Such training may be especially useful in industries such as life insurance, financial services, and real estate where the 
discouragement from low sales success results in high attrition rates for new salespeople. As an example for such training, Dweck (1975) was able to decrease the rate of participant's quitting after receiving negative feedback by training the subjects to make effort attributions for failure.

Finally, we earlier noted that prior studies have found that performance goal orientation has a statistically insignificant relationship with task performance (e.g., Phillips \& Gully, 1997) or that individuals in a performance goal orientation treatment condition had lower task performance than individuals in a learning goal orientation treatment condition (e.g., Block et al., 1995). Based on these studies, it appears that at best, a performance goal orientation is indifferent in its effect on task performance and can sometimes even be deleterious. Given these findings, when managers have a choice between using management practices that are likely to encourage a learning or performance goal orientation, the former is more likely to result in productive outcomes. Thus, managers may want to think twice about using procedures that encourage a performance goal orientation (e.g., competition among colleagues, punishment of mistakes, evaluative appraisal systems) and instead use practices that are more likely to encourage a learning goal orientation (e.g., cooperation among colleagues, encouragement of experimentation, developmental appraisal systems). We believe that the later choices will return a "bigger bang for buck".

\section{Conclusion}

In conclusion, we sought to extend the understanding of the influence of goal orientation on performance. The results indicate a positive relationship between learning goal orientation and performance. This finding is especially interesting for management practice because of the longitudinal research design and objective measure of performance. Further, this study develops an understanding of the self-regulation processes that mediate the relationship of learning goal 
orientation and performance. Understanding of these relationships can help contribute to the selection and management of employees. 


\section{References}

Ames, C. (1992). Classrooms: Goals, structures, and student motivation. Journal of Educational Psychology, 84, 261-271.

Ames, C., \& Archer, J. (1988). Achievement goals in the classroom: Students' learning strategies and motivation processes. Journal of Educational Psychology, 80, 260-267.

Archer, J. (1994). Achievement goals as a measure of motivation in university students. Contemporary Educational Psychology, 19, 430-446.

Baron, R. M., \& Kenny, D. A. (1986). The moderator-mediator variable distinction in social psychological research: Conceptual, strategic, and statistical considerations. Journal of Personality and Social Psychology, 51, 1173-1182.

Block, C. J., Roney, C. J. R., Geeter, J., Lopez, P. D., \& Yang, T. (1995). The influence of situationally induced learning and performance goal orientations on anxiety, motivation and performance on a complex task. Paper presented at the 1995 Academy of Management National Meeting, Vancouver, Canada.

Brown, S. P., Cron, W. L., \& Slocum, J. W. (1997). Effects of goal-directed emotions on salesperson volitions, behavior and performance: A longitudinal study. Journal of Marketing, 61, 39-50.

Brown, S. P., \& Leigh, T. W. (1996). A new look at psychological climate and its relationship to job involvement, effort, and performance. Journal of Applied Psychology, 81, 358368.

Brown, S. P., \& Peterson, R. A. (1994). The effects of effort on sales performance and job satisfaction. Journal of Marketing, 58, 70-80.

Butler, R. (1993). Effects of task- and ego-achievement goals on information-seeking during task engagement. Journal of Personality and Social Psychology, 65, 18-31. 
Button, S., Mathieu, J., \& Zajac, D. (1996). Goal orientation in organizational behavior research: A conceptual and empirical foundation. Organizational Behavior and Human Decision Processes, 67, 26-48.

Churchill, G. A., Ford, N. M., Hartley, S. W., \& Walker, O. C. (1985). The determinants of salesperson performance: A meta-analysis. Journal of Marketing Research, 22, 103-18.

Costa, P. T., Jr., \& McCrae, R. R. (1992). Revised NEO Personality Inventory and NEO Five-Factor Inventory Manual. Odessa, Fl: Psychological Assessment Resources.

Dipboye, R. L., Smith, C. S., \& Howell, W. C. (1994). Understanding industrial organizational psychology. Fort Worth, TX: Harcourt Brace.

Duda, J. L., \& Nicholls, J. G. (1992). Dimensions of achievement motivation in schoolwork and sport. Journal of Educational Psychology, 84, 290-299.

Dweck, C. S. (1975). The role of expectations and attributions in the alleviation of learned helplessness. Journal of Personality and Social Psychology, 31, 674-685.

Dweck, C. S. (1986). Motivational processes affecting learning. American Psychologist, 41, 1040-1048.

Dweck, C. S., \& Leggett, E. L. (1988). A social-cognitive approach to motivation and personality. Psychological Review, 95, 256-273.

Elliott, E. S., \& Dweck, C. S. (1988). Goals: An approach to motivation and achievement. Journal of Personality and Social Psychology, 54, 5-12.

Farr, J. L., Hofmann, D. A., \& Ringenbach, K. L. (1993). Goal orientation and action control theory: Implications for industrial and organizational psychology. In C. L. Cooper and I. T. Robertson (Eds.), International Review of Industrial and Organizational Psychology, 8, 191-232.

Gollwitzer, P. M. (1996). The volitional benefits of planning. In P. M. Gollwitzer \& J. A. Bargh (Eds.), The psychology of action: Linking cognition and motivation to behavior, 287-312. New York: Gullford Press. 
Helmreich, R. L., \& Spence, J. T. (1978). The Work and Family Orientation Questionnaire: An objective instrument to assess components of achievement motivation and attitudes toward family and career. JSAS Catalog of Selected Documents in Psychology, 8, 35

Hoyle, R. H. (1995). Structural equation modeling: Concepts, issues and applications. Thousand Oaks, CA: Sage.

Jackson, D. W., Schlacter, J. L., \& Wolfe, W. G. (1995). Examining the bases utilized for evaluating salespeople's performance. Journal of Personal Selling and Sales Management, 15, 57 66.

Jöreskog, K. G., \& Sörbom, D. (1993). LISREL 8: Strustural equation modeling with the SIMPLIS command language. Chicago: Scientific Software International, Inc.

Kanfer, R. (1990a). Motivational and individual differences in learning: An integration of developmental, differential and cognitive perspectives. Learning and Individual Differences, 2, 221239.

Kanfer, R. (1990b). Motivation theory and industrial and organizational psychology. In M. D. Dunnette and L. Hough (Eds.), Handbook of industrial and organizational psychology, 2nd edition, vol. 1: 75-170. Palo Alto, CA: Consulting Psychologists Press.

Kanfer, R. (1992). Work motivation: New directions in theory and research. In C. L. Cooper and I. T. Robertson (Eds.), International Review of Industrial and Organizational Psychology, 7, 1-53.

Kanfer, R., Ackerman, P.L. \& Heggestad, E. D. (1996). Motivational skills \& selfregulation for learning: A trait perspective. Learning and Individual Differences, 8, 185-209. 
Lee, T. W., Locke, E. A., \& Latham, G. P. (1989). Goal setting theory and job performance. In L. Pervin (Ed.), Goal concepts in personality and social psychology. 291-326. Hillsdale, NJ: L. Erlbaum.

Locke, E. A., \& Latham, G. P. (1990). A theory of goal setting and task performance. Englewood Cliffs, NJ: Prentice Hall.

Loehlin, J. C. (1992). Latent variable models: An introduction to factor, path, and structural analysis, 2nd edition. Hillsdale, NJ: Lawrence Erlbaum Associates.

Miller, R. B., Behrens, J. T., Greene, B. A., \& Newman, D. (1993). Goals and perceived ability: Impact on student valuing, self-regulation and persistence. Contemporary Educational Psychology, 18, 2-14.

Nicholls, J. G. (1984). Achievement motivation: Conceptions of ability, subjective experience, task choice, and performance. Psychological Review, 91, 328-346.

Phillips, J. M., \& Gulley, S. M. (1997). Role of goal orientation, ability, need for achievement, and locus of control in the self-efficacy and goal-setting process. Journal of Applied Psychology, 82, 792-802.

Pinder, C. C. (1998). Work motivation in organizational behavior. Upper Saddle River, NJ: Prentice Hall.

Porter, L., \& Lawler, E. (1968). Managerial attitudes and performance. Homewood, IL: Dorsey.

Ryan, T. (1970). Intentional behavior. New York: Ronald Press.

Scheier, M. F., and Carver, C. S. (1985). Optimism, coping, and health: Assessment and implications of generalized expectancies. Health Psychology, 4, 219-247. 
Smith, K. G., Locke, E. A., \& Barry, D. (1990). Goal setting, planning, and organizational performance: An experimental simulation. Organizational Behavior and Human Decision Processes, 46, 118-134.

Stevens, C. K., \& Gist, M. E. (1997). Effects of self-efficacy and goal orientation on negotiation skill maintenance: What are the mechanisms? Personnel Psychology, $\underline{50}, 955-978$.

Stevens, J. (1996). Applied multivariate statistics for the social sciences, $\underline{\text { 3rd edition. }}$ Hillsdale, JN: Lawrence Erlbaum Associates.

Sujan, H., Weitz, B. A., \& Kumar, N. (1994). Learning orientation, working smart, and effective selling. Journal of Marketing, 58, 39-52.

VandeWalle, D. M. (1996). Are our students trying to prove or improve their ability? Development and validation of an instrument to measure academic goal orientation. Paper presented at the 1996 Academy of Management National Meeting, Cincinnati.

VandeWalle, D. \& Cummings, L.L. (1997). A test of the influence of goal orientation on the feedback seeking process. Journal of Applied Psychology, 82, 390-400.

VandeWalle, D. (1997). Development and validation of a work domain goal orientation instrument. Educational and Psychological Measurement, 8, 995-1015.

Weiss, H. A., \& Adler, S. (1984). Personality and organizational behavior. In B. Staw and L. L. Cummings (Eds.), Research in Organizational Behavior, vol. 6: 1-50. Greenwich, CT: JAI Press.

Williams, E. J. (1959a). The comparison of regression variables. Journal of Royal Statistical Society (Series B), 21, 396-399.

Williams, E. J. (1959b). Regression analysis. New York: John Wiley.

Wood, R., \& Bandura, A. (1989). Social cognitive theory of organizational management. Academy of Management Review, 14, 361-384. 


\section{Table 1}

Means, Standard Deviations and Correlations Among Study Variables

\begin{tabular}{|c|c|c|c|c|c|c|c|c|c|}
\hline Variable & $\underline{\mathrm{M}}$ & $\underline{\mathrm{SD}}$ & 1 & 2 & 3 & 4 & 5 & 6 & 7 \\
\hline 1 Learning Goal Orientation & 6.22 & 0.60 & $(.74)$ & & & & & & \\
\hline 2 Performance Goal Orientation & 5.24 & 0.99 & .35 & $(.81)$ & & & & & \\
\hline 3 Goal Level & 3.25 & 1.29 & .30 & .11 & $(-)$ & & & & \\
\hline 4 Territory Planning & 3.67 & .60 & .44 & .17 & .56 & $(.80)$ & & & \\
\hline 5 Account Planning & 4.10 & .61 & .37 & .20 & .32 & .41 & $(.74)$ & & \\
\hline 6 Effort & 3.81 & .76 & .33 & .07 & .62 & .62 & .35 & $(.92)$ & \\
\hline 7 Sales & 2.79 & 2.25 & .33 & .01 & .69 & .63 & .44 & .64 & $(-)$ \\
\hline
\end{tabular}

Note. Correlations $\geq .24$ are significant at $\mathrm{p}<.001 ; \geq .21$ are significant at $\mathrm{p}<.01$, and $\geq .18$ are significant at $\mathrm{p}<.05$.

Cronbach's $\alpha$ values are reported in the matrix diagonal. 
Table 2a

Multivariate Regression Analysis for Self-regulation Tactics on Learning Goal Orientation

\begin{tabular}{lcc}
\hline Strategy & $\underline{\beta}$ & $\underline{\mathrm{t}}(151)$ \\
\hline Goal Level & 0.30 & $3.87 * * *$ \\
Effort & 0.33 & $4.27 * * *$ \\
Territory Planning & 0.44 & $6.00^{* * *}$ \\
Account Planning & 0.37 & $4.89 * * *$ \\
\hline
\end{tabular}

Table 2b

Multivariate Regression Analysis for Self-regulation Tactics on Performance Goal Orientation

\begin{tabular}{lcc}
\hline Strategy & $\underline{\mathrm{t}}(151)$ \\
\hline Goal Level & 0.11 & 1.42 \\
Effort & 0.07 & 0.82 \\
Territory Planning & 0.17 & $2.17 *$ \\
Account Planning & 0.20 & $2.57 * *$ \\
\hline
\end{tabular}

Note. For Table 2a, Rao's approximate $\underline{F}(4,148)=11.60, \underline{p}<.001$.

For Table 2b, Rao's approximate $\underline{\mathrm{F}}(4,148)=2.31, \underline{\mathrm{p}}=.06$.

$* \mathrm{p}<.05 ; * * \mathrm{p}<.01 ; * * * \mathrm{p}<.001$. 
Table 3

Regression of Sales on Self-regulation Tactics

Step 2

\begin{tabular}{lcc}
\hline Variable & $\underline{\beta}$ & $\underline{\mathrm{t}}(148)$ \\
\hline Goal Level & 0.38 & $5.53^{* * *}$ \\
Territory Planning & 0.22 & $3.16^{* * *}$ \\
Account Planning & 0.15 & $2.63^{* * *}$ \\
Effort & 0.21 & $2.85^{* * *}$ \\
& & \\
$\underline{\mathrm{F}}(4,148)$ & & \\
Adjusted $\mathrm{R}^{2}$ & $56.55 * *$ & \\
\hline
\end{tabular}

$* \underline{\mathrm{p}}<.05 ; * * \mathrm{p}<.01 ; * * * \mathrm{p}<.0001$ 


\section{Table 4}

\section{Analysis of Mediation for Learning Goal Orientation and Sales}

\section{Step 3}

\begin{tabular}{lcc}
\hline Variable & $\underline{\beta}$ & $\underline{\mathrm{t}}(147)$ \\
\hline Goal Level & 0.38 & $5.52 * *$ \\
Territory Planning & 0.22 & $3.07 * *$ \\
Account Planning & 0.15 & $2.58 * *$ \\
Effort & 0.21 & $2.84 * *$ \\
Learning Orientation & 0.00 & -0.08 \\
& & \\
F $(5,147)$ & & \\
Adjusted $\mathrm{R}^{2}$ & .60 & \\
\hline
\end{tabular}

$* \mathrm{p}<.05 ; * * \mathrm{p}<.01 ; * * * \mathrm{p}<.0001$ 


\section{Appendix A}

\section{Goal Orientation Items and Exploratory Factor Analysis Results}

Item Learning Performance

1. Making a tough sale is very satisfying.

2. An important part of being a good salesperson is continually improving your sales skills.

3. It is important for me to learn from each selling experience I have

4. It is worth spending a great deal of time learning new approaches for dealing with customers

5. Learning how to be a better salesperson is of fundamental importance to me.

6. I put in a great deal of effort sometimes in order to learn something new.

7. It is very important to me that my supervisor sees me as a good salesperson.

8. I very much want my co-workers to consider me to be good at selling.

9. I feel very good when I know I have outperformed other salespeople in my company.

10. I always try to communicate my accomplishments to my manager.

11. I spend a lot of time thinking about how my performance compares with other salespeople's. 


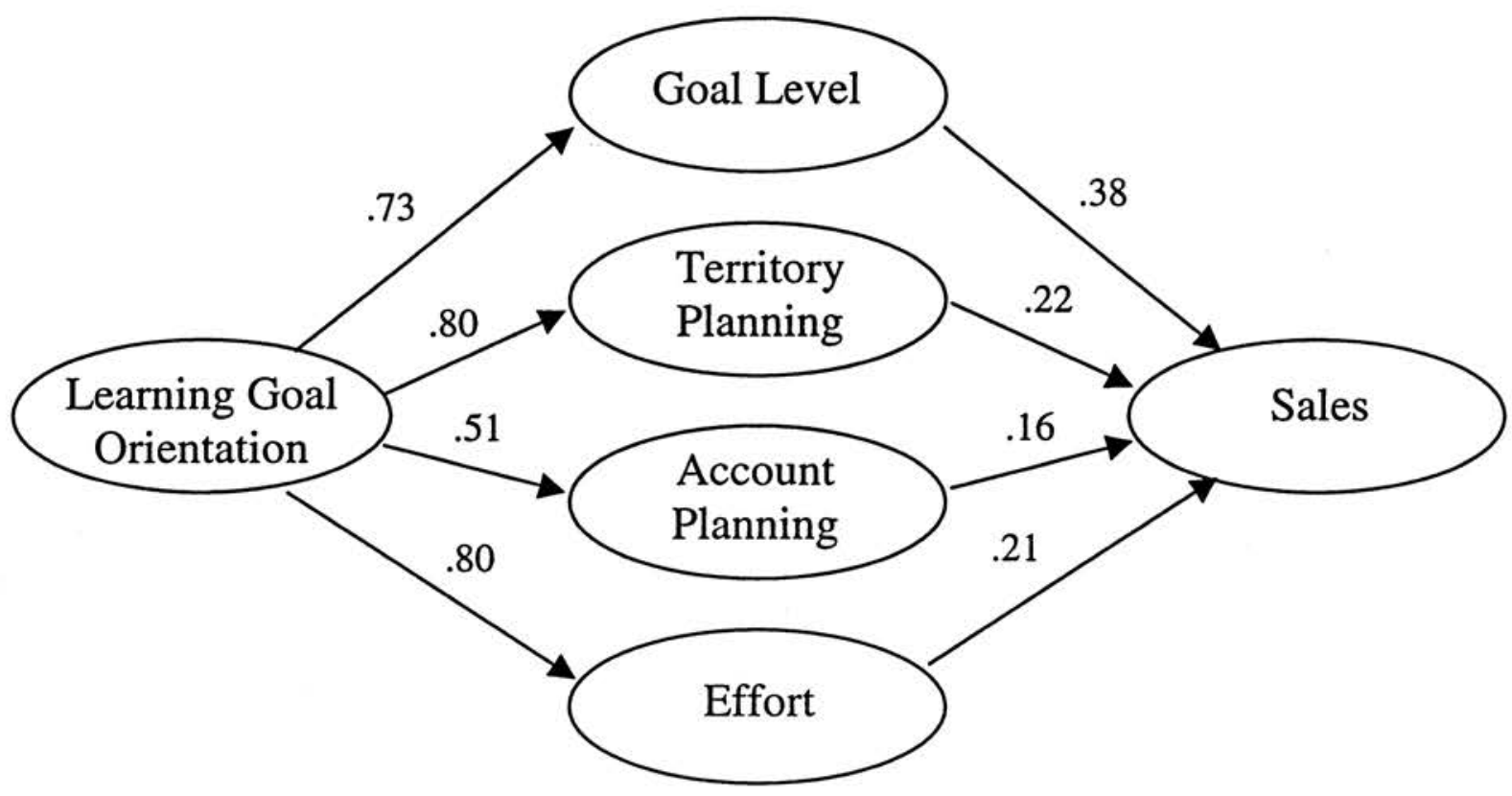

Figure 1. Standardized parameter estimates for the mediated learning goal orientation model. All parameters are statistically significant at $\mathrm{p}<.01$. 
90-0101 "Organizational Subcultures in a Soft Bureaucracy: Resistance Behind the Myth and Facade of an Official Culture," by John M. Jermier, John W.

Slocum, Jr., Louis W. Fry, and Jeannie Gaines

90-0201 "Global Strategy and Reward Systems: The Key Roles of Management Development and Corporate Culture," by David Lei, John W. Slocum, Jr., and Robert W. Slater

90-0701 "Multiple Niche Competition - The Strategic Use of CIM Technology," by David Lei and Joel D. Goldhar

90-1001 “Global Strategic Alliances,” by David Lei and John W. Slocum, Jr.

90-1002 "A Theoretical Model of Household Coupon Usage Behavior And Empirical Test," by Ambuj Jain and Arun K. Jain

90-1003 "Household's Coupon Usage Behavior: Influence of In-Store Search," by Ambuj Jain and Arun K. Jain

90-1201 “Organization Designs for Global Strategic Alliances," by David Lei and John W. Slocum, Jr.

91-0101 "Option-like Properties of Organizational Claims: Tracing the Process of Multinational Exploration,” by Dileep Hurry

91-0701 "A Review of the Use and Effects of Comparative Advertising," by Thomas E. Barry

91-0901 "Global Expansion and the Acquisition Option: The Process of Japanese Takeover Strategy in the United States," by Dileep Hurry

91-0902 "Designing Global Strategic Alliances: Integration of Cultural and Economic Factors," by David Lei and John W. Slocum, Jr.

91-1001 "The Components of the Change in Reserve Value: New Evidence on SFAS No. 69," by Mimi L. Alciatore

91-1002 "Asset Returns, Volatility and the Output Side," by G. Sharathchandra

91-1201 "Pursuing Product Modifications and New Products: The Role of Organizational Control Mechanisms in Implementing Innovational Strategies in the Pharmaceutical Industry," by Laura B. Cardinal

92-0101 "Management Practices in Learning Organizations," by Michael McGill, David Lei, and John W. Slocum, Jr. 
92-0301 "The Determinants of LBO Activity: Free Cash Flow Vs. Financial Distress Costs,' by Tim Opler

92-0302 “A Model of Supplier Responses to Just-In-Time Delivery Requirements," by John R. Grout and David P. Christy

92-0303 "An Inventory Model of Incentives for On-Time Delivery in Just-In-Time Purchasing Contracts," by John R. Grout and David P. Christy

92-0304 "The Effect of Early Resolution of Uncertainty on Asset Prices: A Dichotomy into Market and Non-Market Information," by G.

Sharathchandra and Rex Thompson

92-0305 "Conditional Tests of a Signalling Hypothesis: The Case of Fixed Versus Adjustable Rate Debt," by Jose Guedes and Rex Thompson

92-0306 “Tax-Loss-Selling and Closed-End Stock Funds," by John W. Peavy III

92-0401 "Hostile Takeovers and Intangible Resources: An Empirical Investigation," by Tim C. Opler

92-0402 "Morality and Models," by Richard O. Mason

92-0501 “Global Outsourcing of Information Processing Services," by Uday M. Apte and Richard O. Mason

92-0502 "Improving Claims Operations: A Model-Based Approach," by Uday M. Apte, Richard A. Cavaliere, and G. G. Hegde

92-0503 "Corporate Restructuring and the Consolidation of U.S. Industry," by Julia Liebeskind, Timothy C. Opler, and Donald E. Hatfield

92-0601 “Catalog Forecasting System: A Graphics-Based Decision Support System," by David V. Evans and Uday M. Apte

92-0701 "Interest Rate Swaps: A Bargaining Game Solution," by Uday Apte and Prafulla G. Nabar

92-0702 "The Causes of Corporate Refocusing," by Julia Liebeskind and Tim C. Opler

92-0801 "Job Performance and Attitudes of Disengagement Stage Salespeople Who Are About to Retire," by William L. Cron, Ellen F. Jackofsky, and John W. Slocum, Jr. 
92-0901 "Global Strategy, Alliances and Initiative," by David Lei, and John W. Slocum, Jr.

92-0902 "What's Wrong with the Treadway Commission Report? Experimental Analyses of the Effects of Personal Values and Codes of Conduct on Fraudulent Financial Reporting," by Arthur P. Brief, Janet M. Dukerich, Paul R. Brown, and Joan F. Brett

92-0903 "Testing Whether Predatory Commitments are Credible," by John R. Lott, Jr. and Tim C. Opler

92-0904 "Dow Corning and the Silicone Implant Controversy," by Zarina S. F. Lam and Dileep Hurry

92-0905 "The Strategic Value of Leverage: An Exploratory Study," by Jose C. Guedes and Tim C. Opler

92-1101 "Decision Model for Planning of Regional Industrial Programs," by Uday M. Apte

92-1102 "Understanding the Linkage Between Strategic Planning and Firm Performance: A Synthesis of More Than Two Decades of Research," by C. Chet Miller and Laura B. Cardinal

92-1201 "Global Disaggregation of Information-Intensive Services," by Uday M. Apte and Richard O. Mason

93-0101 "Cost and Cycle Time Reduction in Service Industry: A Field Study of Insurance Claims Operation," by Uday M. Apte and G. G. Hegde

93-0301 "A Robust, Exact Alborithm for the Maximal Set Covering Problem," by Brian T. Downs and Jeffrey D. Camm

93-0501 "The Economic Dependency of Work: Testing the Moderating Effects of Financial Requirements on the Relationship Between Organizational Commitment and Work Attitudes and Behavior," by Joan F. Brett, William L. Cron, and John W. Slocum, Jr.

93-0502 "Unlearning the Organization," by Michael McGill and John W. Slocum, Jr.

93-0503 "The Determinants of Corporate Bank Borrowing," by Linda Hooks and Tim C. Opler 
93-0504 "Corporate Diversification and Innovative Efficiency: An Empirical Study," by Laura B. Cardinal and Tim C. Opler

93-0505 "The Indirect Costs of Financial Distress," by Tim C. Opler and Sheridan Titman

93-0601 "A Mathematical Programming Method for Generating Alternative Managerial Performance Goals After Data Envelopment Analysis," by Jeffrey D. Camm and Brian T. Downs

93-0602 "Empirical Methods in Corporate Finance Used To Conduct Event Studies," by Rex Thompson

93-0801 "A Simple Method to Adjust Exponential Smoothing Forecasts for Trend and Seasonality," by Marion G. Sobol and Jim Collins

93-0901 "Leveraged Buyouts in the Late Eighties: How Bad Were They?" by Jean Helwege and Tim C. Opler

93-0902 “Stock Market Returns and Real Activity: International Evidence," by Thomas C. Harris and Tim C. Opler

93-0914 "Quality Management at Kentucky Fried Chicken,” by Uday M. Apte and Charles C. Reynolds

93-0915 "Global Disaggregation of Information-Intensive Services," by Uday M. Apte and Richard O. Mason

94-0101 "Financial Distress and Corporate Performance," by Tim C. Opler and Sheridan Titman

94-0102 “Models of Incentive Contracts for Just-In-Time Delivery," John R. Grout

94-0103 "Economic Dependency on Work: A Moderator of the Relationship Between Organizational Commitment and Performance," by Joan F. Brett, William L. Cron, and John W. Slocum, Jr.

94-0201 "The Antecedents of Block Share Purchases," by Jennifer E. Bethel, Julia Porter Liebeskind, and Tim C. Opler

94-0202 "The New Learning Strategy: Anytime, Anything, Anywhere," by John W. Slocum, Jr., Michael McGill, and David T. Lei

94-0401 "Leading Learning," by Michael E. McGill and John W. Slocum, Jr. 
94-0402 "Systems Analysis," by Richard O. Mason and Sue A. conger

94-0403 "The Moderating Effects of Insupplier/Outsupplier Status on Organizational Buyer Attitudes," by Steven P. Brown

94-0404 "A Meta-Analytic Study of Nomological Relationships Involving Work Performance and Job Attitudes," by Steven P. Brown and Robert A. Peterson

94-0405 "Strategic Restructuring and Outsourcing: The Effect of Mergers and Acquisitions and LBOs on Building Firm Skills and Capabilities," by David Lei and Michael A. Hitt

94-0406 "Corporate Diversification, Strategic Planning and Performance in Large Multiproduct Firms," by David Lei, Noel Capon, John U. Farley, and James M. Hulbert

94-0407 "Determination of Swap Spreads: An Empirical Analysis," by Andrew H. Chen and Arthur K. Selender

94-0408 "An Analysis of PERCS," by Andrew H. Chen, John Kensinger, and Hansong Pu

94-0409 "Stock Price Reactions to the Passage of the Federal Deposit Insurance Corporation Improvement Act of 1991," by Andrew H. Chen, Marcia Millon Cornett, Sumon C. Mazumdar, and Hassan Tehranian

94-0601 "The Impact of Prior Firm Financial Performance on Subsequent Corporate Reputation," by Sue Annis Hammond and John W. Slocum, Jr.

94-0701 “The VASA Capsizes," by Richard O. Mason

94-0901 "Quality Management in Services: Analysis and Measurement," by Uday Apte, Uday Karmarkar, and Richard Pitbladdo

94-1001 "Absolutely, Positively Operations Research: The Federal Express Story," by Richard O. Mason, James L. McKenney, Walter Carlson, and Duncan Copeland

94-1101 "The Effect of Delivery Windows on the Variance of Flow Time and On-Time Delivery," by John R. Grout

95-0101 "Domestic and Global Outsourcing Practices of America's Most Effective IS Users," by Marion G. Sobol and Uday Apte 
95-0501 "Executive Development in Learning Organizations," by Michael E. McGill and John W. Slocum, Jr.

95-0901 “An Economic Analysis of Inspection Costs for Failsafing Attributes," by John R. Grout and Brian T. Downs

96-0101 "Some Intriguing Relationships in Business Teaching Evaluations," by Thomas E. Barry and Rex Thompson

96-0501 "Designing Lateral Organizations: An Analysis of the Benefits, Costs, and Enablers of Nonhierarchical Organizational Forms," by William F. Joyce, Victor E. McGee, and John W. Slocum, Jr.

96-0701 "Effects of Goal-Directed Emotions on Salesperson Volitions, Behavior and Performance: A Longitudinal Study," by Steven P. Brown, William L. Cron, and John W. Slocum, Jr.

96-0801 "Optimization of Dual Response Systems: A Comprehensive Procedure for Degenerate and Nondegenerate Problems," by Enrique Del Castillo, Shu-Kai Fan, and John Semple

97-0201 “A Little Leadership, Please?," by Michael E. McGill and John W. Slocum

97-0301 "Inventory Under Consignment," by John Semple and Brian Downs

97-1001 “A Direct Approach for Managing Inventory with Lost Sales, Intermittent Demand, and Resource Contraints," by John Semple and Brian Downs

97-1002 “Optimal Service Design: Integrating Marketing and Operations Elements for Capacity Decisions," by Madeleine E. Pullman and William Moore

98-0201 "Effects of Trait Competitiveness and Perceived Intraorganizational Competition on Salesperson Goal Setting and Performance," by Steven P. Brown, William L. Cron and John W. Slocum, Jr.

98-0202 "The Organization Design Labyrinth: From Tradeoffs to Learning," by David Lei, John W. Slocum, Jr., and Robert A. Pitts

98-0301 "An Analysis of the Production Line versus the Case Manager Approach to Information Intensive Services," by Uday M. Apte, Cynthia M. Beath, and Chon-Huat Goh 